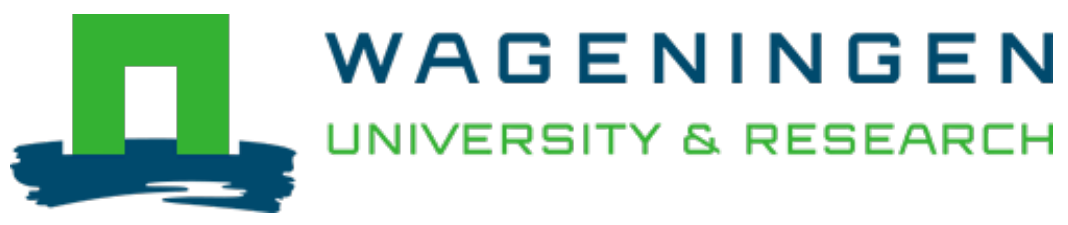

\title{
Understanding possible causes of exceeding dioxin levels in palm oil by-products: An explorative study
}

\author{
Food Control \\ Taverne-Veldhuizen, Wilma; Hoogenboom, Ron; Dam, Guillaume; Herbes, Rik; Luning, Pieternel \\ https://doi.org/10.1016/j.foodcont.2019.106777
}

This article is made publicly available in the institutional repository of Wageningen University and Research, under the terms of article $25 \mathrm{fa}$ of the Dutch Copyright Act, also known as the Amendment Taverne. This has been done with explicit consent by the author.

Article 25 fa states that the author of a short scientific work funded either wholly or partially by Dutch public funds is entitled to make that work publicly available for no consideration following a reasonable period of time after the work was first published, provided that clear reference is made to the source of the first publication of the work.

This publication is distributed under The Association of Universities in the Netherlands (VSNU) 'Article $25 \mathrm{fa}$ implementation' project. In this project research outputs of researchers employed by Dutch Universities that comply with the legal requirements of Article $25 \mathrm{fa}$ of the Dutch Copyright Act are distributed online and free of cost or other barriers in institutional repositories. Research outputs are distributed six months after their first online publication in the original published version and with proper attribution to the source of the original publication.

You are permitted to download and use the publication for personal purposes. All rights remain with the author(s) and / or copyright owner(s) of this work. Any use of the publication or parts of it other than authorised under article $25 \mathrm{fa}$ of the Dutch Copyright act is prohibited. Wageningen University \& Research and the author(s) of this publication shall not be held responsible or liable for any damages resulting from your (re)use of this publication.

For questions regarding the public availability of this article please contact openscience.library@,wur.nl 


\title{
Understanding possible causes of exceeding dioxin levels in palm oil by- products: An explorative study
}

\author{
Wilma Taverne-Veldhuizen ${ }^{\mathrm{a}}$, Ron Hoogenboom ${ }^{\mathrm{b}}$, Guillaume ten Dam ${ }^{\mathrm{b}, 1}$, Rik Herbes ${ }^{\mathrm{c}}$, \\ Pieternel Luning,
}

${ }^{a}$ Wageningen UR - Food Quality and Design, Bornse Weilanden 9, 6708 WG, Wageningen, the Netherlands

${ }^{\mathrm{b}}$ RIKILT - Wageningen UR, Akkermaalsbos 2, $6708 \mathrm{WB}$, Wageningen, the Netherlands

${ }^{\mathrm{c}}$ Nederlandse Voedsel en Warenautoriteit, Catharijnesingel 59, 3511 GG, Utrecht, the Netherlands

\section{A R T I C L E I N F O}

\section{Keywords:}

Palm

Oil refining

Palm fatty acid distillate

Hydrogenated

Non-regulated dioxins

Regulated dioxins

\begin{abstract}
A B S T R A C T
The Rapid Alert System for Food and Feed (period 1999-2014) reported exceeding levels of dioxins (polychlorinated dibenzo-p-dioxinsand dibenzofurans (PCDD/Fs)) in palm oil by-products, such as palm fatty acid distillate (PFAD) and hydrogenated palm fatty acid distillate (HPFAD), but not in crude and refined palm oil. The aim of the present study was to gain insight into the occurrence and congener profiles of dioxin contamination during industrial processing of crude palm oil into refined oil and its by-products PFAD and HPFAD via analysis of individual congener concentrations. In total, 1217 samples from an industrial process were collected at four different points, crude palm oil at delivery $(\mathrm{N}=202)$, fresh bleaching earth before bleaching $(\mathrm{N}=84)$, PFAD after deodorising palm oil $(\mathrm{N}=553)$, and HPFAD after hydrogenation of PFAD $(\mathrm{N}=378)$. Congener profiles were analysed by GC-HRMS, and toxic equivalent (TEQ) levels were calculated using toxic equivalence factors (TEF) of $\mathrm{WHO}_{2005}$ to assess non-compliance to legal limits. All dioxin levels in crude palm oil samples were far below the action limit. All dioxin levels in fresh bleaching earth were in compliance with the maximum level. For the by-product samples, such as PFAD, $0.6 \%$ exceeded the action level, but all were below the maximum level (ML). However, for $1.3 \%$ of the HPFAD samples, the TEQ level exceeded the ML.

In-depth analysis of the congener profiles revealed that after the hydrogenation step, the concentration of the lower chlorinated congeners in the HPFAD samples was higher than in the PFAD samples. The hydrogen atoms possibly replaced the chlorine atoms during hydrogenation. As these lower chlorinated congeners have a higher TEF, when they are regulated, their contribution to the calculated TEQ is higher, which resulted in some HPFAD samples exceeding the legal limit. Further research is needed to obtain insight into the changes in PCDD/F congener profiles during the hydrogenation of palm oil products.
\end{abstract}

\section{Introduction}

The control of chemical hazards is important for food and feed safety and consumer trust (Directorate-General_for_Health\&Consumers, 2013; Jackson, 2009; TNS_Opinion\&Social, 2010). One of the concerns of chemical hazards are the dioxins, more precisely polychlorinated dibenzo-p-dioxins (PCDDs) and dibenzofurans (PCDFs), and dioxin likepolychlorinated biphenyls (DL-PCBs). Dioxins are toxic components that persist in the environment in abundance and accumulate in the food chain (EFSA, 2010; 2012a; 2012b). As a result, fish and food of animal origin mostly contribute to human exposure. However, dioxins may be present in plant-derived products, including crude oil like crude coconut oil and fatty acid distillate products, such as palm fatty acid distillate, coconut fatty acid distillate, deodistillate, and hydrogenated palm fatty acid distillate (FEDIOL, 2013b). Strict limits have been set within the European Union to reduce the levels of dioxins in the food chain, and as a result, human exposure. Limits were set according to the principle "strict but feasible", based on the observed levels in each type of product. Further reduction of the limits can be expected based on the EFSA opinion published in 2018 (EFSA, 2018). Exceeding the limits does not necessarily mean a direct risk for consumers, but a notification via the rapid alert system for food and feed (RASFF), subsequently

\footnotetext{
* Corresponding author.

E-mail addresses: Wilma.Taverne@wur.nl (W. Taverne-Veldhuizen), Ron.Hoogenboom@wur.nl (R. Hoogenboom), guillaume.ten.dam@dspsystems.eu (G.t. Dam), Rik.herbes@nvwa.nl (R. Herbes), Pieternel.Luning@wur.nl (P. Luning).

${ }^{1}$ Present address Food Valley BTA12, Darwinstraat 7a, 6718 XR, Ede, The Netherlands.
} 


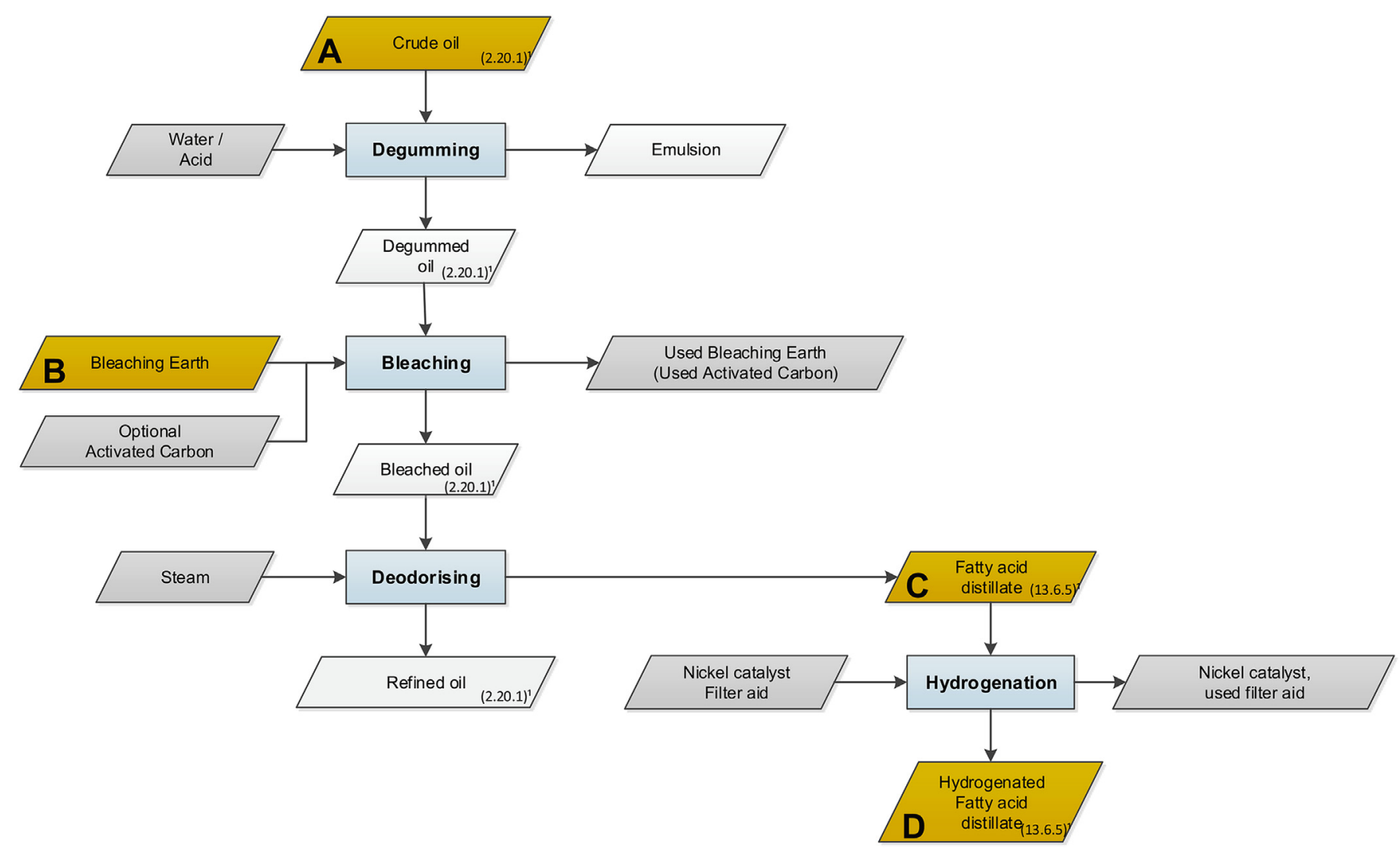

Fig. 1. Sampling points in the palm oil refining process: crude palm oil (sample point A, 202 samples), fresh bleaching earth (sample point B, 84 samples), fatty acid distillate (sample point C, 553 samples), and hydrogenated fatty acid distillate (sample point D, 378 samples).

published in the newspapers, can have a considerable negative impact on consumer trust with large economic consequences for the food or feed industries (Directorate-General_for_Health\&Consumers, 2011).

Dioxins cover a group of 75 PCDDs and 135 PCDFs. Seventeen of these are of toxicological concern and are regulated (EC, 2006). These 17 congeners are common in that the chlorine atoms are at positions 2 , 3, 7 and 8 (De Meulenaer, 2006). The degree of chlorination and the pattern of substitution are responsible for inter-congener differences in chemical behaviour, persistence, and toxic potency (Schecter, Birnbaum, Ryan, \& Constable, 2006). To deal with the latter, each of the 17 congeners has been assigned a toxic equivalency factor (TEF), which has to be multiplied by the actual concentration, resulting in the toxic equivalent (TEQ) level. Toxic equivalency factors are regularly evaluated and adapted based on new scientific information, and the last evaluation was in 2005 (Van den Berg et al., 2006). In general, more chlorine atoms correspond with a lower TEF. The current $\mathrm{WHO}_{2005^{-}}$ TEFs vary from 0.0003 to 1 for PCDD/Fs. The sum of the toxic equivalents for all individual congeners has to be compared with the regulatory limit, which is expressed in toxic equivalents $\left(\mathrm{WHO}_{2005}{ }^{-}\right.$ TEQ). For fat products, to be used in food for human consumption, the limit is set at $0.75 \mathrm{pg} \mathrm{WHO}_{2005}$-PCDD/F-TEQ per gram fat (EC, 2011; 2014b). The regulatory limit for plant-derived fat products for feed is also set at $0.75 \mathrm{ng} \mathrm{WHO}_{2005}$-PCDD/F-TEQ per kilogram product based on $12 \%$ moisture (EC, 2012; 2014c). In the RASFF reports, the levels of PCDD/Fs and DL-PCBs are only presented as TEQ levels, and therefore do not provide information about the congener pattern and or concentrations of individual congeners.

In the period 1999-2014, 10 notifications in the RASFF system were reported on plant-derived products and mainly for palm oil by-products, such as palm fatty acid distillate (PFAD) and hydrogenated palm fatty acid distillate (HPFAD) but not for crude and refined palm oil. The dioxin levels ranged from 1.04 to $2.29 \mathrm{ng} \mathrm{WHO}_{2005}-\mathrm{TEQ} / \mathrm{kg}$, the highest one was three times the maximum level. In the past, elevated and sometimes more extreme levels of PCDD/Fs and DL-PCBs in food or feed were attributed to human errors, mostly unintentionally. However, in some cases, it was fraud, as in the case of the use of technical fatty acids for the production of feed (Abraham et al., 2011). This resulted in a major incident in Germany in 2010. The dioxin levels in the fatty acids were $123-124 \mathrm{ng}$ WHO-TEQ $2005 / \mathrm{kg}$, which was $>150$ times the maximum level. However, in animal-derived products, the highest levels exceeded the limits only to a small extent. Nevertheless, the incident showed the vulnerability of the food chain and had an impact on consumer trust.

To effectively control dioxins and maintain consumer trust, it is necessary to understand the presence and behaviour of dioxins in palm products for food and feed applications. To the best of our knowledge, only a limited number of studies have provided insight into dioxin presence and its behaviour during the refining of palm oil (Van Asselt \& Sterrenburg, 2011). The presence of dioxins has been described for oils and fats, especially in fish oil. The reduction of dioxin TEQ values has been reported for refining of fish oil by activated carbon adsorption (Oterhals, 2011; Oterhals, Kvamme, \& Berntssen, 2010). However, the effects of processing on all dioxin congeners throughout the palm oil/ fat refining and hydrogenation process have not yet been described.

The aim of this study was to explore the presence of regulated and non-regulated dioxins in crude palm oil and the by-products palm fatty acid distillate (PFAD) and hydrogenated palm fatty acid distillate (HPFAD). For this purpose, we measured the concentrations of the regulated dioxin congeners in industrial palm oil monitoring samples. Furthermore, we also analysed, for a selected number of samples, the concentrations of both the regulated and non-regulated dioxin congeners. 
Table 1

Polychlorinated dibenzo-p-dioxins and polychlorinated dibenzofurans (PCDD/F) congeners detected in crude palm oil (CPO, 202 samples), fresh bleaching earth (FBE, 84 samples), palm fatty acid distillate (PFAD, 553 samples) and hydrogenated palm fatty acid distillate (HPFAD, 378 samples) and the \% of the samples above action/maximum level.

\begin{tabular}{|c|c|c|c|c|c|c|c|c|}
\hline Congener PCDD/F & $\begin{array}{l}\text { CPO } \\
\text { Percentage } \\
\text { above LOQ }{ }^{\mathrm{a}} \\
(\%)\end{array}$ & $\begin{array}{l}\text { CPO } \\
\text { Maximum } \\
\left(\text { median }^{\mathrm{c}}\right) \\
\text { concentration (ng/ } \\
\mathrm{kg} \text { ) }\end{array}$ & $\begin{array}{l}\text { FBE } \\
\text { Percentage } \\
\text { above LOQ } \\
(\%)\end{array}$ & $\begin{array}{l}\text { FBE } \\
\text { Maximum } \\
\text { (median) } \\
\text { concentration } \\
\text { (ng/kg) }\end{array}$ & $\begin{array}{l}\text { PFAD } \\
\text { Percentage } \\
\text { above LOQ } \\
(\%)\end{array}$ & $\begin{array}{l}\text { PFAD } \\
\text { Maximum } \\
\left(\text { median }^{\mathrm{c}} \text { ) }\right. \\
\text { concentration (ng/ } \\
\mathrm{kg} \text { ) }\end{array}$ & $\begin{array}{l}\text { HPFAD } \\
\text { Percentage } \\
\text { above LOQ } \\
(\%)\end{array}$ & $\begin{array}{l}\text { HPFAD } \\
\text { Maximum } \\
\left(\text { median }^{c}\right) \\
\text { concentration (ng/ } \\
\mathrm{kg} \text { ) }\end{array}$ \\
\hline $2,3,7,8-\mathrm{TCDD}$ & 0.5 & 0.06 & 39.3 & 0.31 & 0.7 & 0.09 & 1.3 & 0.12 \\
\hline $1,2,3,7,8-\mathrm{PeCDD}$ & 0.5 & 0.06 & 59.5 & $0.39(0.11)$ & 8.3 & 0.30 & 16.7 & 0.65 \\
\hline $1,2,3,4,7,8-\mathrm{HxCDD}$ & 0.5 & $0.96^{\mathrm{b}}$ & 59.5 & $0.67(0.10)$ & 43.8 & 0.28 & 68.8 & $2.06(0.09)$ \\
\hline $1,2,3,6,7,8-\mathrm{HxCDD}$ & 2.5 & 0.12 & 73.8 & $1.04(0.21)$ & 71.4 & $0.56(0.10)$ & 82.3 & $2.05(0.16)$ \\
\hline $1,2,3,7,8,9-\mathrm{HxCDD}$ & 11.9 & 0.27 & 77.4 & $2.00(0.53)$ & 85.4 & $1.27(0.20)$ & 91.3 & $3.33(0.31)$ \\
\hline $1,2,3,4,6,7,8-\mathrm{HpCDD}$ & 53.0 & $2.57(0.09)$ & 91.7 & $21.7(3.50)$ & 98.2 & $6.00(1.01)$ & 99.0 & $36.1(3.94)$ \\
\hline OCDD & 90.6 & $198(9.27)$ & 95.2 & $485(38.1)$ & 99.8 & $394(31.4)$ & 100 & $345(24.5)$ \\
\hline 2,3,7,8-TCDF & 1.5 & 0.16 & 58.3 & $2.01(0.07)$ & 21.9 & 0.77 & 14.3 & 0.29 \\
\hline $1,2,3,7,8-\mathrm{PeCDF}$ & 1.5 & 0.09 & 28.6 & 0.54 & 10.1 & 0.25 & 4.2 & 0.86 \\
\hline $2,3,4,7,8-\mathrm{PeCDF}$ & 0.5 & 0.12 & 45.2 & 0.45 & 10.7 & 0.72 & 4.2 & 0.22 \\
\hline $1,2,3,4,7,8-\mathrm{HxCDF}$ & 1.0 & 0.06 & 23.8 & 0.16 & 6.5 & 3.79 & 2.7 & 0.23 \\
\hline $1,2,3,6,7,8-\mathrm{HxCDF}$ & 0.5 & 0.06 & 23.8 & 0.25 & 4.5 & 0.16 & 3.7 & 0.37 \\
\hline $1,2,3,7,8,9-\mathrm{HxCDF}$ & 1.5 & 1.70 & 10.7 & 0.74 & 2.2 & 0.18 & 1.3 & 0.12 \\
\hline $2,3,4,6,7,8-\mathrm{HxCDF}$ & 1.0 & 0.75 & 17.9 & 0.32 & 4.5 & 0.11 & 2.9 & 0.39 \\
\hline $1,2,3,4,6,7,8-\mathrm{HpCDF}$ & 6.9 & 0.27 & 41.7 & 0.46 & 20.3 & 0.59 & 15.3 & 1.40 \\
\hline $1,2,3,4,7,8,9-\mathrm{HpCDF}$ & 1.5 & 3.73 & 1.2 & 0.08 & 2.2 & 0.29 & 2.9 & 0.69 \\
\hline \multirow[t]{2}{*}{ OCDF } & 2.0 & 0.35 & 13.1 & 0.46 & 1.1 & 0.57 & 0.8 & 0.40 \\
\hline & \multicolumn{2}{|l|}{$\mathrm{CPO}$} & \multicolumn{2}{|l|}{ FBE } & \multicolumn{2}{|l|}{ PFAD } & \multicolumn{2}{|l|}{ HPFAD } \\
\hline $\begin{array}{l}\text { \% samples above } \\
\text { action level } \\
\text { (expressed in } \\
\text { TEQ) }\end{array}$ & \multicolumn{2}{|l|}{$0 \%$} & \multicolumn{2}{|c|}{ No action level } & \multicolumn{2}{|l|}{$0.6 \%$} & \multicolumn{2}{|l|}{$6.6 \%$} \\
\hline $\begin{array}{l}\text { \% samples above } \\
\text { maximum level } \\
\text { (expressed in } \\
\text { TEQ) }\end{array}$ & \multicolumn{2}{|l|}{$0 \%$} & \multicolumn{2}{|c|}{ FEDIOL limit: $0 \%$} & \multicolumn{2}{|l|}{$0 \%$} & \multicolumn{2}{|l|}{$1.3 \%$} \\
\hline
\end{tabular}

a LOQ is limit of quantification.

b The total congener pattern deviated, but as there is no confirmation of failure the reported value is taken into account.

c Median is mentioned in breakage when it was not the LOD.

\section{Material and methods}

\subsection{Materials}

Industrial refining and hydrogenation of palm oil result in refined palm oil and the by-products palm fatty acid distillate (PFAD) and hydrogenated palm fatty acid distillate (HPFAD). All are commercial products used in the food and/or feed industry. Fig. 1 shows the process flow including the 4 sampling points.

From 2011 till 2014, a total of 1217 samples were collected at four different points; 202 crude palm oil samples, 84 fresh bleaching earth samples, and 553 palm fatty acid distillate samples, and 378 hydrogenated palm fatty acid distillate samples.

The first point of sample collection (sample code A, 202 samples) was the crude palm oil after loading seagoing vessels in different countries of origin (Brazil, Indonesia, and Malaysia). Samples were sent to the laboratories in Europe and analysed while the vessel was sailing to Europe. The crude palm oil (CPO) samples, were collected according to the ISO 5555, the protocol for animal and vegetable fats and oils sampling. The CPO samples were ships' tanks samples, collected by an accredited surveyor. The samples were sent to two commercial European laboratories, both ISO 17025 certified and having dioxin analysis as part of their scope. To understand the total congener pattern, eight samples were analysed at the Dutch Reference Laboratory (NRL) for determination of the concentration of the individual 2,3,7,8PCDD/F and non-2,3,7,8-PCDD/F congeners.

The second point of sampling was the fresh bleaching earth (sample code B, 84 samples) because it is a processing aid that may contain dioxins. Fresh bleaching earth was purchased based on the European Oil and Protein meal Industry requirements for fresh bleaching earth (FEDIOL, 2013a). The maximum level specified for the sum of PCDD/Fs and DL-PCBs is $1.5 \mathrm{ng} \mathrm{WHO}_{2005}$-TEQ/kg. Analyses were performed by three commercial laboratories with ISO 17025 certification. In total, 84 fresh bleaching earth samples were analysed. From these 84 samples, 7 samples from three different suppliers were analysed at the Dutch NRL for the determination of the concentration of the individual 2,3,7,8$\mathrm{PCDD} / \mathrm{F}$ and non-regulated PCDD/F congeners and the potential contribution to the PCDD/F concentration in oil after bleaching.

The third sampling point was after deodorising (sample code C, 553 samples), this is a steam stripping distillation process at high temperature where the free fatty acids are removed. This point was selected because during this steam stripping distillation process, dioxins may be transferred into the by-product fatty acid distillate. Palm fatty acid distillate (PFAD) samples were taken from storage tanks. The monitoring of PFAD is based on $100 \%$ monitoring and connected to the crude palm oil monitoring. The sampling strategy was based on ISO 5555. These samples were taken by an accredited surveyor or trained person. The standard monitoring analyses were done at two commercial European laboratories. From 6 samples, the 17 regulated PCDD/F congeners and the non-regulated congeners were analysed at the Dutch NRL to get insight into the concentration of the individual 2,3,7,8$\mathrm{PCDD} / \mathrm{F}$ and non-2,3,7,8-PCDD/F congeners.

The last sampling point was directly after hydrogenation of the fatty acid distillate (sample code D, 378 samples). Fatty acid distillate and hydrogenated fatty acid distillate are both feed ingredients. The hydrogenated palm fatty acid distillate (HPFAD) samples were taken from 


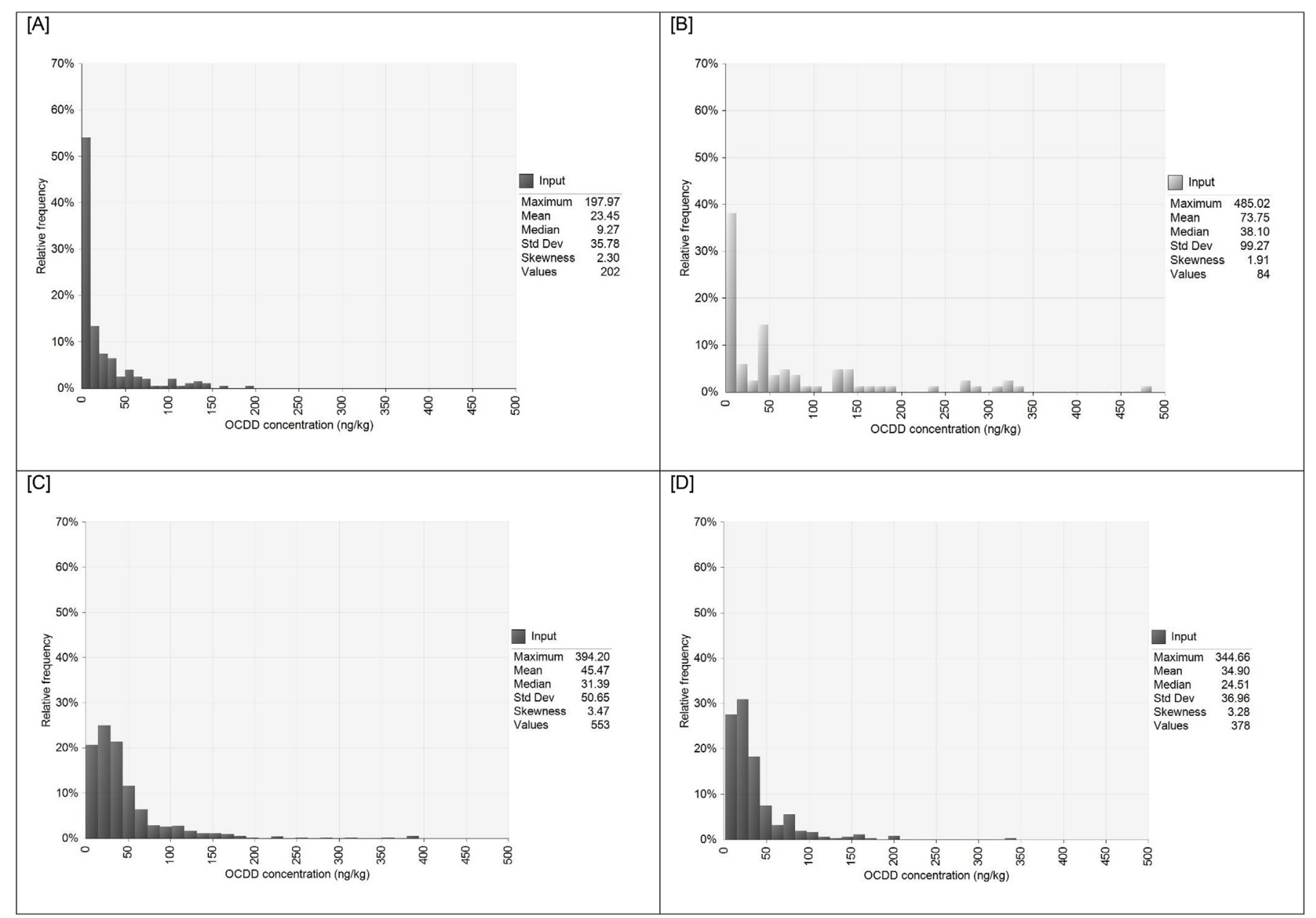

Fig. 2. Concentrations of OCDD detected in the monitoring samples taken at the four sampling points: crude palm oil (A), fresh bleaching earth (B), palm fatty acid distillate (C), and hydrogenated palm fatty acid distillate (D).

storage tanks and analysed. Moreover, these samples were collected by an accredited surveyor or trained person. From these HPFADs, 5 samples were selected to measure the concentration of the individual 2,3,7,8-PCDD/F and non-2,3,7,8-PCDD/F congeners.

\subsection{Methods}

At the moment of the study, the requirements for analysis were described in Commission Regulations (EU) No 709/2014 and (EU) No 589/2014 (EC, 2014a; 2014c). In 2017 the requirements for dioxin analyses were upgraded and published in Commission Regulation (EU) No 2017/644. The laboratories, which performed the regulated dioxin congener analyses, were accredited following the EN ISO/IEC 17025 standard (International Standardization Organization, ISO). The laboratories performed well during the participation in inter-laboratory studies for the determination of PCDD/F in relevant food and feed matrices and concentration ranges.

The crude oil, palm fatty acid, and palm fatty acid distillate were analysed according to the accredited method.

A selected set of the monitoring samples was analysed at the Dutch NRL for both the regulated 2,3,7,8-PCDD/F and non-regulated PCDD/F congeners. The quantification of the non-regulated PCDD/F congeners is not part of the accreditation. For the analysis, solutions of all individual regulated and non-regulated PCDD/Fs were purchased from Cambridge Isotope laboratories (Comprehensive Polychlorinated Dioxin and Furan Column Defining Kit, CIL-JR-PCDD/F-KIT), as well as ${ }^{13} \mathrm{C}$-labeled internal standards of 2-MCDF; 2,3,8-TrCDF; 2-MCDD; and
2,3,7-TrCDD. In addition, standards and internal standards for the official analysis of regulated PCDD/Fs were used for quantification. All samples were spiked with $50 \mathrm{pg}$ of ${ }^{13} \mathrm{C}$-labeled PCDD/Fs, while other $\mathrm{PCDD} / \mathrm{Fs}$ were spiked to at least one sample per analytical series for identification and quality control purposes. Since all of the non-2,3,7,8PCDD/Fs were not available for the first batch of the samples, quantification was performed on the initially available congeners (at least one per constitutional 2,3,7,8-substituted isomer with the nearest retention time). For these samples, identification was retrospectively performed based on relative retention times.

For the analysis of CPO, PFAD, and HPFAD, due to the poor solubility of the samples, $2.5 \mathrm{~g}$ of sample was spiked with ${ }^{13} \mathrm{C}$-labeled standards, and then mixed with $50 \mathrm{ml}$ heated hexane (approximately $40{ }^{\circ} \mathrm{C}$ ) and $10 \mathrm{~g}$ of acidified silica $\left(40 \% \mathrm{H}_{2} \mathrm{SO}_{4}\right)$. Following overnight incubation, the supernatant was filtered and reduced till $25 \mathrm{ml}$ and purified using an automated clean-up system (PowerPrep, Fluid Management Systems (FMS.), Waltham, USA). In this system, extracts were purified on four columns prepared with acid silica, neutral silica, basic alumina, and activated carbon/celite. For the elution of the columns, several solvents and mixtures were used, such as hexane, hexane/dichloromethane $(1: 1, \mathrm{v} / \mathrm{v})$, ethyl acetate/toluene $(1: 1, \mathrm{v} / \mathrm{v})$, and toluene. The volume of the final extract was reduced to $0.5 \mathrm{ml}$ using an automated evaporation system, with the fixed endpoint of $0.5 \mathrm{ml}$. These extracts were purified once more over a funnel with a piece of glass wool, $1.5 \mathrm{~g}$ silica and $2.5 \mathrm{~g}$ acidified silica $\left(40 \% \mathrm{H}_{2} \mathrm{SO}_{4}\right)$ and eluted with $15 \mathrm{ml}$ hexane to remove interferences causing suppression in the instrumental analysis. The volume of the final extract 


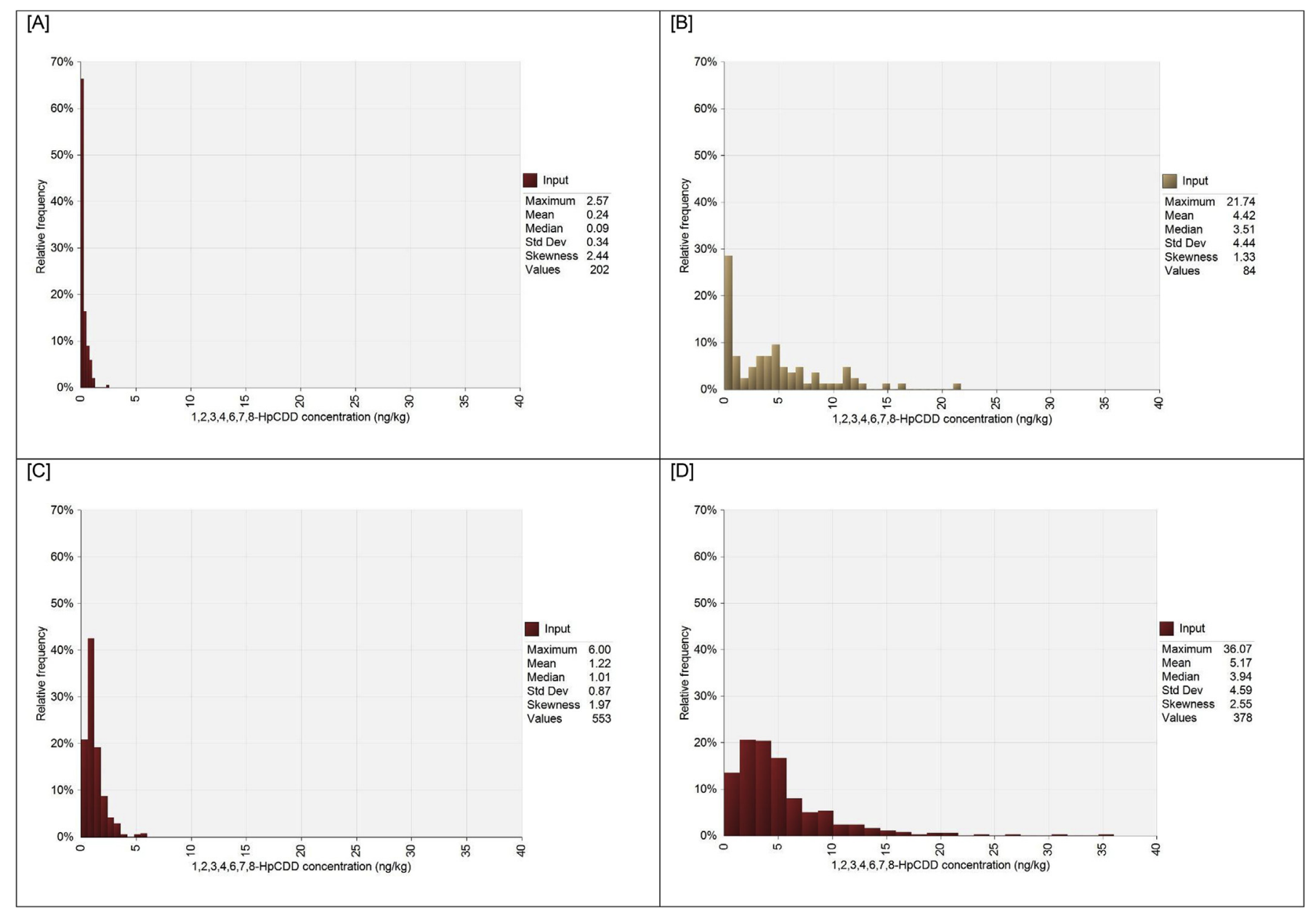

Fig. 3. Concentrations of $1,2,3,4,6,7,8-\mathrm{HpCDD}$ detected in the monitoring samples taken at the four sampling points: crude palm oil (A), fresh bleaching earth (B), palm fatty acid distillate (C), and hydrogenated palm fatty acid distillate (D).

was again reduced to $0.5 \mathrm{ml}$ using an automated evaporation system, with the fixed endpoint of $0.5 \mathrm{ml}$. The instrumental recovery standards ${ }^{13} \mathrm{C}$-labeled 1,2,3,4-TCDD and 2,3,4,6,7,8-HxCDF were added, and the volume of the extract again reduced to $0.5 \mathrm{ml}$. Analysis of PCDD/Fs was performed by GC/HRMS using an Agilent (Wilmington, USA) 6890 Series gas chromatograph and an AutoSpec Ultima high resolution mass spectrometer (Waters, Milford, USA) operated in electron impact ionization at a resolution of 10,000 (10\% peak valley) in single ion recording mode, monitoring 2 mono isotopic masses per (labeled) congener of which the ratio in response was used for identification. The GC column was a DB5 MS $(60 \mathrm{~m}, 0.25 \mathrm{~mm}$ i.d., $0.25 \mu \mathrm{m}$; J\&W, Folson, USA). A large volume injector (LVI) from Gerstel (Mülheim an der Ruhr, Germany) was used to inject $100 \mu$ of the extract in a glass beads liner in the solvent vent mode with a speed of $0.95 \mu \mathrm{l} / \mathrm{s}$ at $70{ }^{\circ} \mathrm{C}, 0 \mathrm{kPa}$ ventpressure resulting in a pressure of $\sim 15 \mathrm{kPa}$ needed to reach the set vent flow of $100 \mathrm{ml} / \mathrm{min}$ with a vent time of $2.2 \mathrm{~min}$ on the PTV injector. After the initial time of $2.25 \mathrm{~min}$, the PTV was ramped at $720^{\circ} \mathrm{C} / \mathrm{min}$ till $280^{\circ} \mathrm{C}$ and kept at this temperature during the whole run. The oven was initially set at $110^{\circ} \mathrm{C}$ for $3 \mathrm{~min}$ and ramped to $200^{\circ} \mathrm{C}$ with $20^{\circ} \mathrm{C} / \mathrm{min}$, a second ramp of $4^{\circ} \mathrm{C} / \mathrm{min}$ was applied till $280^{\circ} \mathrm{C}$, and this temperature was maintained for $7.5 \mathrm{~min}$. A third ramp of $10^{\circ} \mathrm{C} / \mathrm{min}$ was applied till $320^{\circ} \mathrm{C}$ and maintained for $8 \mathrm{~min}$. All analytical results are expressed in $\mathrm{ng}$ per $\mathrm{kg}$ based on the product.

Fresh bleaching earth samples were extracted using Accelerated Solvent Extraction (ASE, Thermo Fisher Dionex, Sunnyvale, USA). From the sample, $10 \mathrm{~g}$ of homogenized fresh bleaching earth was spiked with ${ }^{13} \mathrm{C}$-labeled standards. Subsequently, the samples were mixed with approximately $8 \mathrm{~g}$ diatomaceous earth and transferred to an ASE cell, which was extracted 3 times for $15 \mathrm{~min}$ with toluene:ethanol $(9: 1, \mathrm{v} / \mathrm{v})$ at $100{ }^{\circ} \mathrm{C}$ and 1500 PSI. The extract was filtered over a funnel with anhydrous $\mathrm{Na}_{2} \mathrm{SO}_{4}$, and the solvent evaporated in a rotavapor to approximately $2 \mathrm{ml}$ and reconstituted in hexane. The extract was purified according to the procedure described for the Dutch Reference Laboratory.

For assessing regulatory compliance, the concentration of each congener was multiplied with the specific $\mathrm{WHO}_{2005}$-TEF, whereby 2,3,7,8-tetrachlorodibenzo-p-dioxin (2,3,7,8-TCDD) and 1,2,3,7,8-pentachlorodibenzo-p-dioxin (1,2,3,7,8-PeCDD) have a TEF of 1 . The lowest TEF, 0.0003 , is for octachlorodibenzo-p-dioxin (OCDD) and octachlorodibenzofuran (OCDF), with the maximum of 8 chlorine atoms. Supplementary material B shows the 17 regulated 2,3,7,8-PCDD/F congeners and the $\mathrm{WHO}_{2005}$-TEF related to each congener (Commission Regulation (EU) No 1259/2011 and 277/2012). The concentration multiplied with TEF is resulting in Toxic Equivalents (TEQ) expressed in ng $\mathrm{WHO}_{2005}$-TEQ per kg. For PCDD/Fs, the total Toxic Equivalence $\left(\mathrm{TEQ}_{2005}\right)=\Sigma \mathbf{i}_{=1-7}(\mathrm{PCDDi} * \mathrm{TEFi})+\mathrm{j}_{=1-10}(\mathrm{PCDFj} * \mathrm{TEFj})(\mathrm{i}=7$ PCDD and $\mathrm{j}=10 \mathrm{PCDF}$ ). The total value is expressed in a lower bound (LB) value, excluding the non-detected congeners, and an upper bound (UB) value, using the limit of quantification (LOQ) for the non-detected congeners, which is then multiplied with the TEF. The LOQ is not a fixed value and dependent on the laboratory. The UB value has to be compared with the maximum level mentioned in the regulation. The non-regulated PCDD/Fs have no $\mathrm{WHO}_{2005}$-TEF assigned, and therefore, they have no contribution to the total TEQ value.

The distribution of OCDD and 1,2,3,4,6,7,8-heptachlorodibenzo-pdioxin (HpCDD) and their concentrations in the 4 monitoring steps 


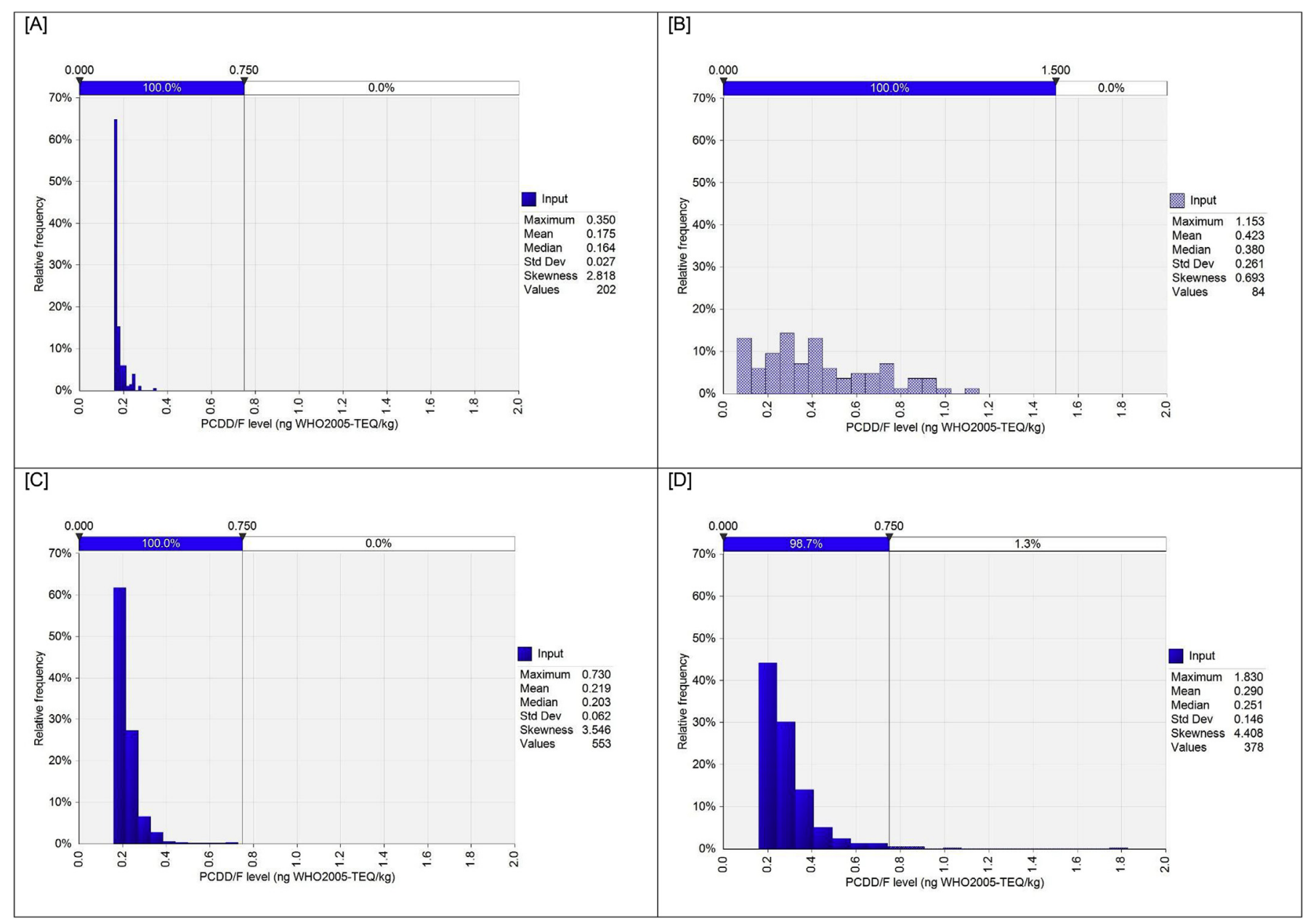

Fig. 4. $\mathrm{PCDD} / \mathrm{Fs}$ levels, expressed in the upper bound $\mathrm{WHO}_{2005}-\mathrm{TEQ}$, detected in the monitoring samples at the four sampling points: crude palm oil (A), fresh bleaching earth (B), palm fatty acid distillate (C), and hydrogenated palm fatty acid distillate (D). The bars above the figures show the maximum level and fraction of samples exceeding the maximum level.

were visualized, based on relative frequency plots made with the Risk package from Palisade.

\section{Results}

\section{1. $P C D D / F s$ detected in routine monitoring}

Table 1 shows the monitoring results of the samples at the four sampling points (samples coded A, B, C, and D, as indicated in the process scheme in Fig. 1), expressed as the fraction of PCDD/F congeners measured above the limit of quantification (LOQ) and the maximum concentration of the congener measured in routine monitoring. Table 1 shows the percentage of samples above the action level and maximum level as well.

In crude palm oil (CPO, sample code A), in $90.6 \%$ of the samples, the level of OCDD was above the LOQ. The concentration varied from < LOQ till $198 \mathrm{ng} / \mathrm{kg}$, whereby the median was $9.3 \mathrm{ng} / \mathrm{kg}$. In $53 \%$ of these samples, the concentration of $1,2,3,4,6,7,8$-HpCDD was above the LOQ, the concentration being in the range of $<$ LOQ till $2.57 \mathrm{ng} / \mathrm{kg}$. For this congener, the median was $0.09 \mathrm{ng} / \mathrm{kg}$. The congeners $2,3,7,8$ TCDD and 1,2,3,7,8-PeCDD were both detected once (0.5\%), showing a level of $0.06 \mathrm{ng} / \mathrm{kg}$. This is $>1000$-fold lower compared to the concentration of OCDD. With a maximum concentration of $198 \mathrm{ng} / \mathrm{kg}$ for OCDD, the highest contribution of this congener to the TEQ level was $0.06 \mathrm{ng} \mathrm{WHO}_{2005}-\mathrm{TEQ} / \mathrm{kg}$, similar to the highest level for TCDD and $1,2,3,7,8-\mathrm{PeCDD}$. This means that the absolute concentration can be significantly different, whereas the TEQ levels are similar. Although dioxin congeners are present, all samples were below the action and maximum level due to the presence of high chlorinated congeners with low TEF value.

Table 1 also shows the results for fresh bleaching earth samples (FBE, sample code B). The OCDD was detected in $95.2 \%$ of the samples in the range of $<$ LOQ till $485 \mathrm{ng} / \mathrm{kg}$ (median was $38.1 \mathrm{ng} / \mathrm{kg}$ ). Other congeners detected were 1,2,3,4,6,7,8-HpCDD; 1,2,3,7,8,9-HxCDD; 1,2,3,6,7,8-HxCDD; 1,2,3,4,7,8-HxCDD; 1,2,3,7,8-PeCDD; and 2,3,7,8TCDF. The highest contribution of OCDD to the total TEQ level was thus $0.15 \mathrm{ng} \mathrm{WHO}_{2005}-\mathrm{TEQ} / \mathrm{kg}$. Overall, this means that when $1 \%$ fresh bleaching earth (Patterson, 1992) with $485 \mathrm{ng} / \mathrm{kg}$ OCDD was added to the palm oil the maximum contamination of the crude palm oil would be $4.85 \mathrm{ng} / \mathrm{kg}\left(0.0015 \mathrm{ng} \mathrm{WHO}_{2005}-\mathrm{TEQ} / \mathrm{kg}\right)$. For 1,2,3,4,6,7,8-HpCDD, this was $0.22 \mathrm{ng} / \mathrm{kg}\left(0.0022 \mathrm{ng} \mathrm{WHO}_{2005}-\mathrm{TEQ} / \mathrm{kg}\right)$.

After bleaching, in a physical refining process, the oil is deodorised, whereby the free fatty acids (FFA) are removed, resulting in palm fatty acid distillate (PFAD). Part of the PFAD is subsequently hydrogenated to hydrogenated palm fatty acid distillate (HPFAD). In Table 1, the dioxin monitoring results for both PFAD (sample code C) and HPFAD (sample code D) are presented as well. The maximum and median OCDD concentrations in PFAD were 394 and $31.4 \mathrm{ng} / \mathrm{kg}$, respectively. The maximum and median OCDD concentrations in HPFAD were 345 and $24.5 \mathrm{ng} / \mathrm{kg}$, respectively. The maximum 1,2,3,4,6,7,8-HpCDD concentration in PFAD was $6.00 \mathrm{ng} / \mathrm{kg}$ (median $1.01 \mathrm{ng} / \mathrm{kg}$ ), while in HPFAD the maximum concentration was $36.1 \mathrm{ng} / \mathrm{kg}$ (median $3.94 \mathrm{ng}$ / 

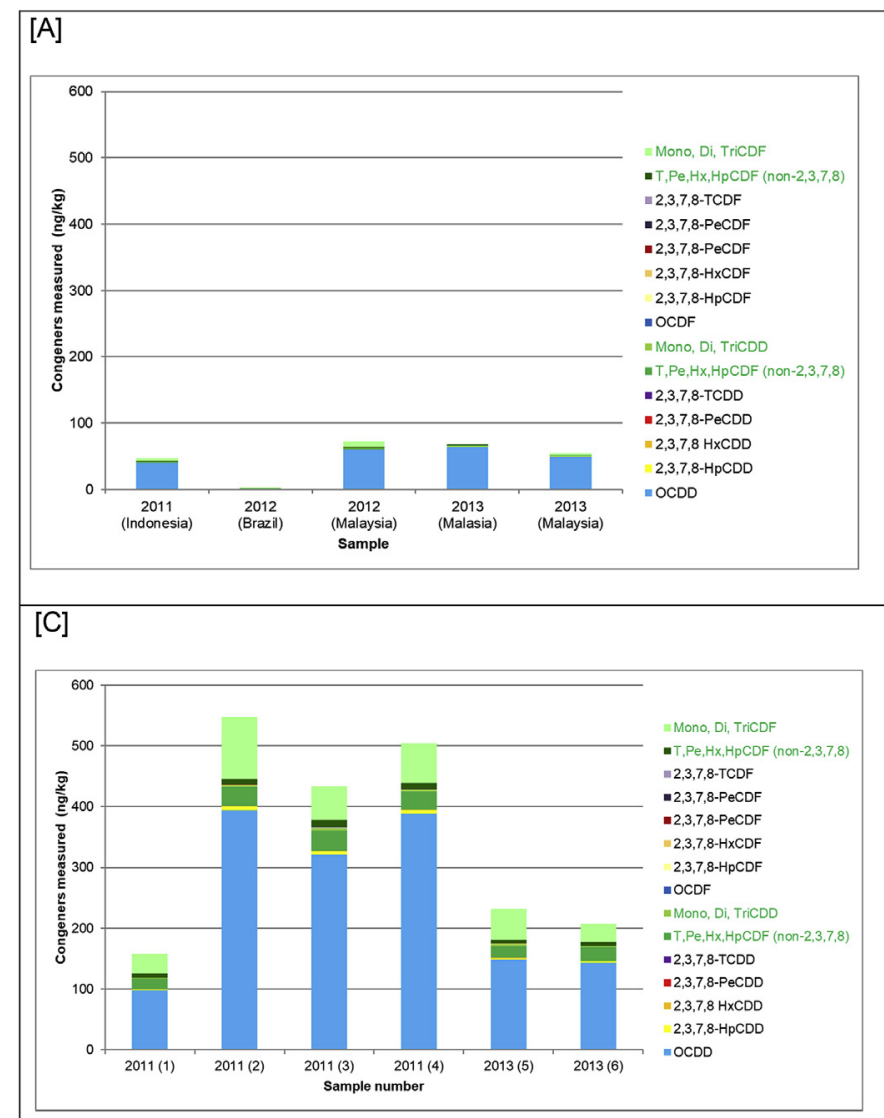

[B]

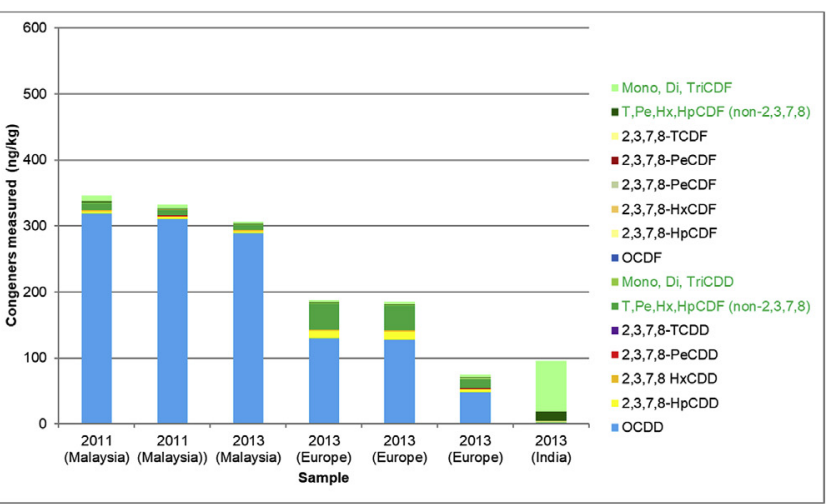

[D]

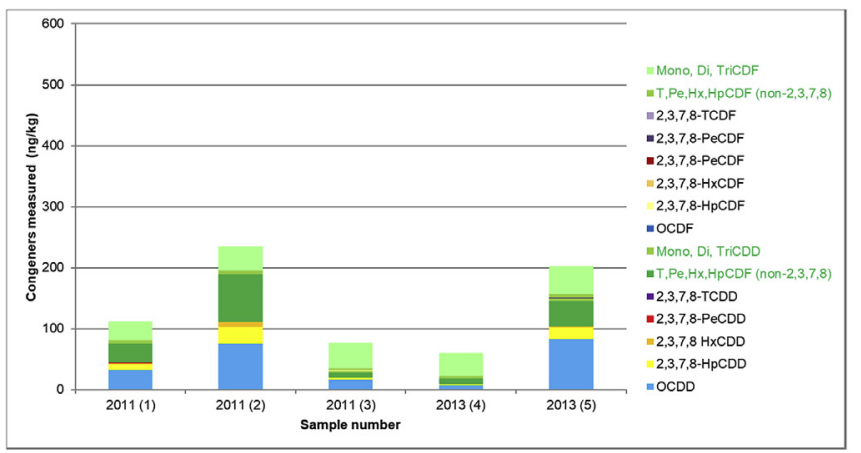

Fig. 5. $P C D D / F$ congeners profiles of crude palm oil samples $(N=5)(A)$, fresh bleaching earth samples $(N=7)(B)$, palm fatty acid samples $(N=6)(C)$, and samples of hydrogenated palm fatty acid distillate $(\mathrm{N}=5)(\mathrm{D})$.

$\mathrm{kg}$ ).

From the PFAD samples, $0.6 \%$ was above the action level; however, all were below the maximum level. From the HPFAD samples, $6.6 \%$ were above the action level, and $1.3 \%$ was above the regulatory maximum level (Table 1).

\subsection{Frequency of $O C D D, 1,2,3,4,6,7,8-H p C D D$, and TEQ levels at the four different sampling points}

Relative distribution curves were made for samples from all four sampling points when a congener was above the LOQ in more than $50 \%$ of the samples. This was only applicable for OCDD (Fig. 2) and 1,2,3,4,6,7,8-HpCDD (Fig. 3). Fig. 4 shows the TEQ levels.

Figs. 2A-3A show the relative distribution of OCDD and $1,2,3,4,6,7,8-\mathrm{HpCDD}$ concentrations in crude palm oil. The average concentration of OCDD was $23.5 \mathrm{ng} / \mathrm{kg}$ when the non-detects were considered as $0 \mathrm{ng} / \mathrm{kg}$. The median was $9.27 \mathrm{ng} / \mathrm{kg}$. The distribution was right skewed (2.3), which explains the difference between median and average. The average $1,2,3,4,6,7,8-\mathrm{HpCDD}$ concentration was $0.24 \mathrm{ng} / \mathrm{kg}$ when the non-detects were considered as $0 \mathrm{ng} / \mathrm{kg}$, the median $0.09 \mathrm{ng} / \mathrm{kg}$. The distribution was right skewed (2.4) as well. Fig. 4A shows that all results expressed in $\mathrm{WHO}_{2005}$-TEQ were well below the maximum level.

Figs. 2B-3B show the relative distribution of OCDD and $1,2,3,4,6,7,8$-HpCDD concentrations in the 84 fresh bleaching earth samples. The average OCDD concentration was $73.8 \mathrm{ng} / \mathrm{kg}$ when the non-detects were considered as $0 \mathrm{ng} / \mathrm{kg}$, the median $38.1 \mathrm{ng} / \mathrm{kg}$. The skewness was 1.9 . The average $1,2,3,4,6,7,8-\mathrm{HpCDD}$ concentration was $4.42 \mathrm{ng} / \mathrm{kg}$ when the non-detects were considered as $0 \mathrm{ng} / \mathrm{kg}$, the median $3.50 \mathrm{ng} / \mathrm{kg}$. The skewness was 1.3 . The contribution of the dioxin concentration of the added fresh bleaching earth $(1 \%)$ to the concentration of dioxin in the crude palm oil is low. Fig. 4B shows the results expressed in $\mathrm{WHO}_{2005}$-TEQ, none of the samples exceeding the maximum level as specified by FEDIOL, the European vegetable oil and protein meal industry association, as regulatory limit does not exist for this product.

Figs. 2C-3C show the relative distribution of the concentration of OCDD and 1,2,3,4,6,7,8-HpCDD in palm fatty acid distillate. The average concentration of OCDD was $45.5 \mathrm{ng} / \mathrm{kg}$ when the non-detects were considered as $0 \mathrm{ng} / \mathrm{kg}$, the median $31.4 \mathrm{ng} / \mathrm{kg}$. The distribution was right skewed (3.5). The average $1,2,3,4,6,7,8-\mathrm{HpCDD}$ concentration was $1.22 \mathrm{ng} / \mathrm{kg}$ when the non-detects were considered as $0 \mathrm{ng} / \mathrm{kg}$, the median $1.01 \mathrm{ng} / \mathrm{kg}$. Comparison of Figs. 2A-3A and 2C-3C suggests that the dioxin congeners concentrate in the PFAD during deodorising. The distribution was right skewed (2.0). Fig. 4C showed that all results were below the regulatory limit; however, as reported in Table 1, $0.6 \%$ of the PFAD samples were above the action limit of $0.5 \mathrm{ng} \mathrm{WHO}_{2005}{ }^{-}$ TEQ/kg fat.

Figs. 2D and 3D show the relative distribution of the concentration of OCDD and 1,2,3,4,6,7,8-HpCDD in hydrogenated palm fatty acid distillate. The average concentration of OCDD was $34.9 \mathrm{ng} / \mathrm{kg}$ when the non-detects were considered as $0 \mathrm{ng} / \mathrm{kg}$, the median $24.5 \mathrm{ng} / \mathrm{kg}$. The distribution was right skewed (3.3). The average 1,2,3,4,6,7,8-HpCDD concentration was $5.17 \mathrm{ng} / \mathrm{kg}$ when the non-detects were considered as $0 \mathrm{ng} / \mathrm{kg}$, the median $3.94 \mathrm{ng} / \mathrm{kg}$. The distribution was right skewed (2.5). Table 1 and Fig. 4D shows that $6.6 \%$ of the samples exceeded the action level, and $1.3 \%$ of the samples showed a $\mathrm{WHO}_{2005}$-TEQ level

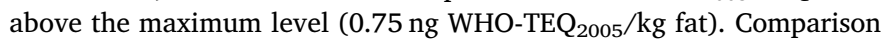
of Figs. 2C-3C and 2D-3D suggests that dioxins hydrogenate as well.

Although limited, there appears to be a shift in the TEQ levels 

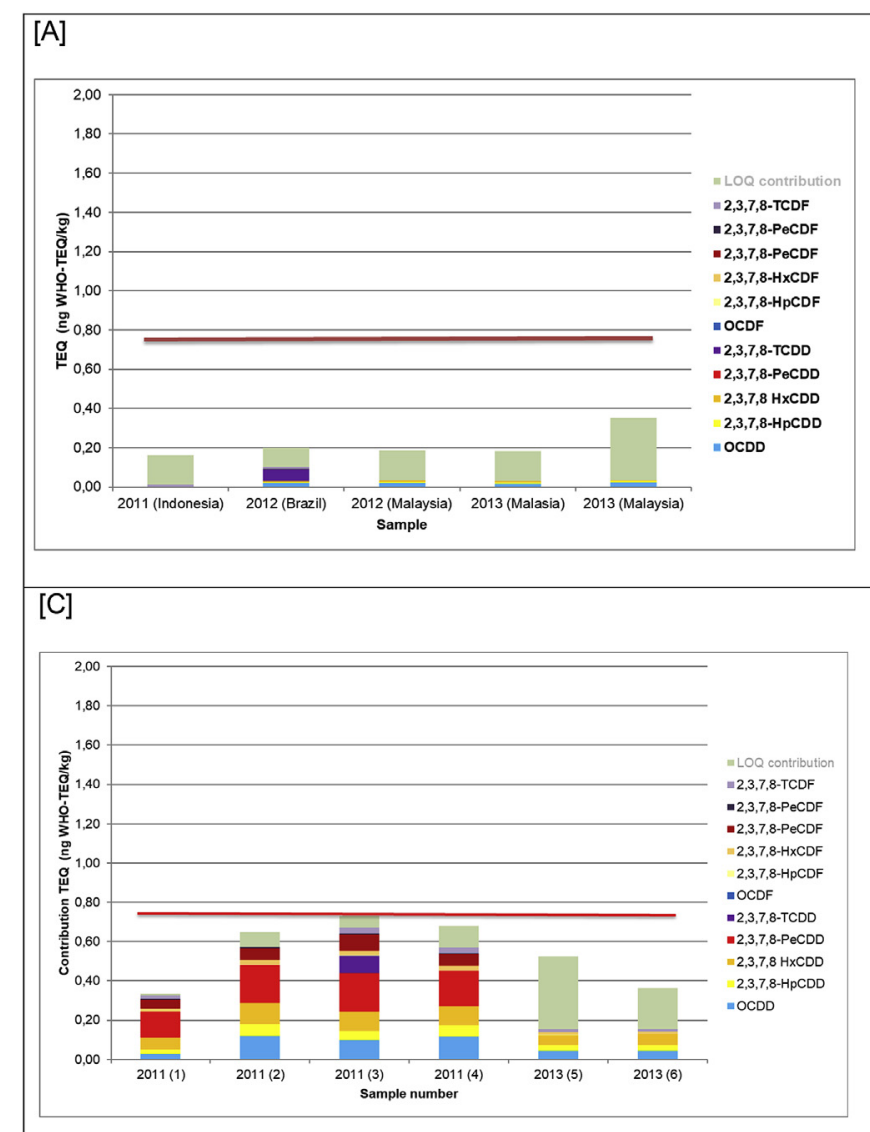

[B]

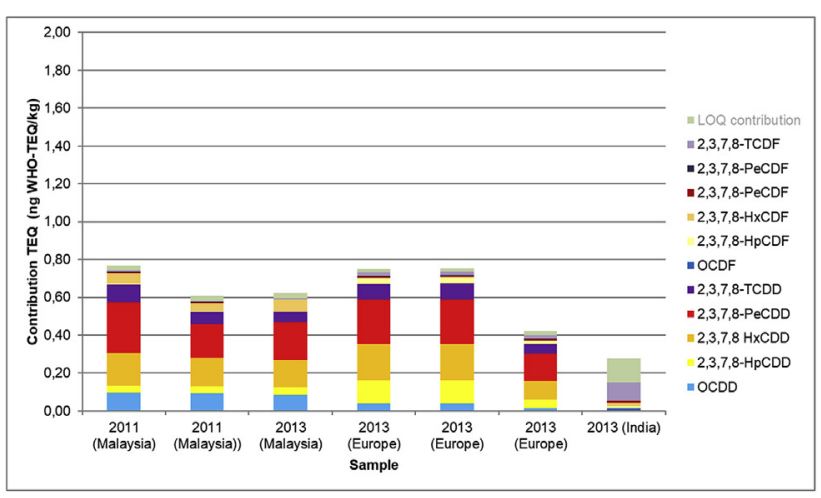

[D]

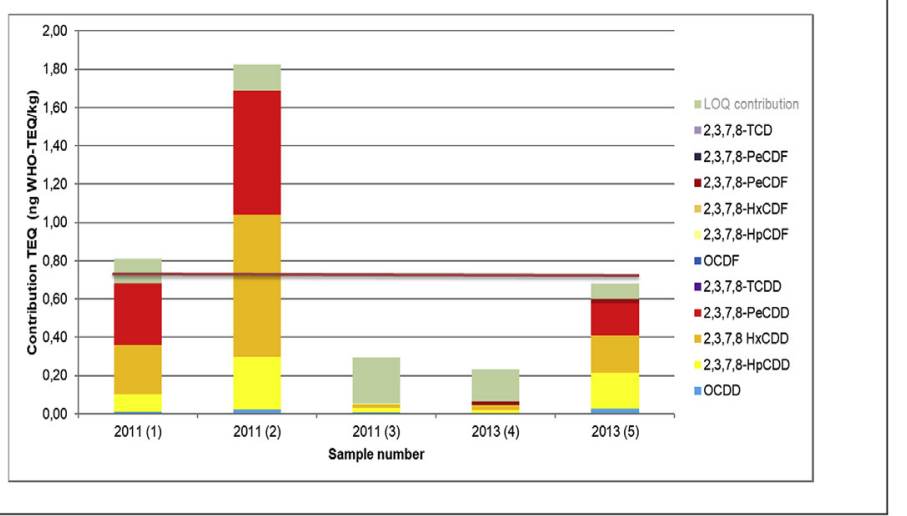

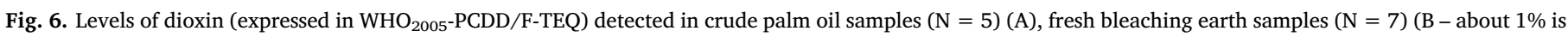
added to palm oil), palm fatty acid samples $(\mathrm{N}=6)(\mathrm{C})$, and samples of hydrogenated palm fatty acid distillate $(\mathrm{N}=5)(\mathrm{D})$.

between crude palm oil and PFAD, and subsequently from PFAD to HPFAD. In most cases, this has no effect on the compliance of the samples, but in some cases, the levels in HPFAD are above the maximum level. When focusing on congeners, the main congener in crude palm oil, PFAD, and HPFAD was OCDD, followed by $1,2,3,4,6,7,8$ HpCDD. The highest OCDD concentration was detected in PFAD, the lowest in crude palm oil, while the highest concentration of $1,2,3,4,6,7,8-\mathrm{HpCDD}$ was in HPFAD. Overall, the HpCDD levels in HPFAD showed a broader range than in PFAD and CPO. This may point to a possible conversion of OCDD to lower chlorinated PCDD/Fs, thus increasing the TEQ levels. In addition, there might be an increase in both regulated and non-regulated lower chlorinated congeners. Thus, a number of samples were investigated for both the 2,3,7,8-PCDD/F and non-2,3,7,8-PCDD/F congeners.

\subsection{Levels and patterns of regulated and non-regulated $P C D D / F$ congeners}

Fig. 5 shows the concentration of the congeners and Fig. 6 shows the contribution of the individual congeners expressed in $\mathrm{WHO}_{2005}-\mathrm{PCDD} /$ F-TEQ for the different sample points (A, B, C, D). The exact data are reported in supplementary material $\mathrm{B}$.

Fig. 5A shows the PCDD/F concentrations in the crude palm oil (CPO) samples with a known origin taken at five different points in the distribution curve. The total regulated PCDD/F concentration was between 1.55 and $65.0 \mathrm{ng} / \mathrm{kg}$. The concentrations of non-2,3,7,8 congeners were low (1.05-11.7 ng/kg; green bar). The OCDD was the main congener in the range of 1.29 till $64.2 \mathrm{ng} / \mathrm{kg}$ (blue bar). Fig. 5A shows that the concentrations $(\mathrm{ng} / \mathrm{kg}$ ) fluctuated. However, the impact on the $\mathrm{WHO}_{2005}$-TEQ was limited (due to the OCDD $\mathrm{TEF}_{2005}$ of 0.0003 it was $0.02 \mathrm{ng} \mathrm{WHO}_{2005}-\mathrm{TEQ} / \mathrm{kg}$ ). Fig. $6 \mathrm{~A}$ shows the congener-specific TEQ levels expressed in $\mathrm{WHO}_{2005}$-PCDD/F-TEQ, whereby the red line indicates the regulatory limit for food. For each congener, the TEQ was calculated based on the concentration multiplied by TEF (Toxic Equivalence Factor) of that particular congener. The TEF values are listed in supplementary material B. The TEQ level for these samples varied from 0.16 to $0.20 \mathrm{ng} \mathrm{WHO}_{2005}-\mathrm{PCDD} / \mathrm{F}-\mathrm{TEQ} / \mathrm{kg}$. In sample 1 , the reported upper bound TEQ level was mainly a result of LOQ contribution. The PCDD/F level expressed in $\mathrm{WHO}_{2005}$-TEQ for all five samples was far below the regulatory limit.

Figs. 5B-6B show the results of the 7 fresh bleaching earth (FBE) samples, which were further analysed. The fresh bleaching earth samples originated from three different regions (Asia, Europe, and India) resulting in three different profiles. The total PCDD/F concentration was between 74.2 and $345.9 \mathrm{ng} / \mathrm{kg}$, whereby the non-2,3,7,8-PCDD/F congener concentration was between 11.5 and $92.5 \mathrm{ng} / \mathrm{kg}$ and the 2,3,7,8-PCDD/F congener concentration between 2.75 and $325 \mathrm{ng} / \mathrm{kg}$. When oil is treated with $1 \%$ of these fresh bleaching earths and all $\mathrm{PCDD} / \mathrm{Fs}$ migrate to the oil, the potential maximum contamination is in the range of 0.74 and $3.46 \mathrm{ng} / \mathrm{kg}$. The sample '2013 (India) with the lowest concentration 2,3,7,8-PCDD/F congeners had the highest concentration non-2,3,7,8-PCDD/F congeners. The PCDD congeners were present based on the colours applied for the congeners. The main regulated congener present was OCDD (blue bar), 1.13 till $318 \mathrm{ng} / \mathrm{kg}$, resulting in a potential contribution to the crude palm oil between 0.011 and $3.2 \mathrm{ng} / \mathrm{kg}$ when only fresh bleaching earth was used. Fig. 6B shows low concentrations of 1,2,3,7,8-PeCDD and 2,3,7,8-TCDD, resulting in a higher TEQ level, as shown in the red and purple part of the bar. The TEQ level is ranging between 0.28 till $0.77 \mathrm{ng} \mathrm{WHO}_{2005}$-TEQ/ $\mathrm{kg}$, which means that the potential contribution to the oil is between 0.0028 and $0.0077 \mathrm{ng} \mathrm{WHO}_{2005}-\mathrm{TEQ} / \mathrm{kg}$. As reported in the fish 
refining literature, activated carbon can be used in combination with fresh bleaching earth. When activated carbon is used, then there is no release of dioxin into the oil.

Figs. 5C-6C show the results of six palm fatty acid distillate (PFAD) samples, analysed in-depth. The concentration of non-2,3,7,8-PCDD/F congeners was between 57.5 and $145 \mathrm{ng} / \mathrm{kg}(21-36 \%$ of the total $\mathrm{PCDD} / \mathrm{F}$ concentration). The concentration of the regulated 2,3,7,8$\mathrm{PCDD} / \mathrm{F}$ congeners in the six PFAD samples was between 101 and $402 \mathrm{ng} / \mathrm{kg}$, where the main congener, OCDD, was in the range of 97.6 till $394 \mathrm{ng} / \mathrm{kg}$. This indicates that both the regulated and the nonregulated PCDD/F congeners transfer to the PFAD. The TEQ level was in the range of 0.36 till $0.73 \mathrm{ng} \mathrm{WHO}_{2005}-\mathrm{PCDD} / \mathrm{F}-\mathrm{TEQ} / \mathrm{kg}$.

Figs. 5D-6D show the results of the 5 hydrogenated palm fatty acid distillate (HPFAD) samples, which were analysed in-depth. The concentration of non-2,3,7,8-PCDD/F congeners was between 50.8 and $124 \mathrm{ng} / \mathrm{kg}$ (being $49-84 \%$ of the total PCDD/F concentration) due to the presence of non-regulated congeners (green bars). The concentration of the regulated PCDD/F congeners in the 5 HPFAD samples was between 9.25 and $111 \mathrm{ng} / \mathrm{kg}$, where the main congener OCDD was in the range of 7.35 till $82.5 \mathrm{ng} / \mathrm{kg}$ (blue bar). The toxic equivalence level was in the range of 0.23 till $1.82 \mathrm{ng} \mathrm{WHO}_{2005}-\mathrm{PCDD} / \mathrm{F}-\mathrm{TEQ} / \mathrm{kg}$. The higher TEQ level was caused by the presence of 1,2,3,7,8-PeCDD with a TEF of $1(<\mathrm{LOQ}-0.65 \mathrm{ng} / \mathrm{kg}$ ) and 2,3,7,8-HxCDD with a TEF of 0.1 . Overall, in these HPFAD samples, the concentration of regulated PCDD/ Fs was lower compared to the PFAD samples, which showed higher OCDD contributions. However, the concentration of the lower chlorinated 2,3,7,8-PCDD/F congeners was higher, resulting in a higher TEQ level compared to PFAD samples.

\section{Discussion}

In the RASFF database from 1999 till June 2014, 10 palm oil byproducts exceeded the maximum levels for dioxins, but no notifications were reported for crude and refined palm oil (see supplementary material A). Therefore, the PCDD/F concentrations and related TEQ levels were studied in monitoring samples from industrial processing. These samples were taken from the raw material 'crude palm oil', the processing aid 'fresh bleaching earth', the by-product 'palm fatty acid distillate' (PFAD), and the by-product 'hydrogenated palm fatty acid distillate' (HPFAD).

In the 202 crude palm oil samples taken from the raw material flow (Fig. 2A), a maximum OCDD concentration of $198 \mathrm{ng} / \mathrm{kg}$ was found with an average of $36 \mathrm{ng} / \mathrm{kg}$, a median of $9.3 \mathrm{ng} / \mathrm{kg}$, and a standard deviation of $36 \mathrm{ng} / \mathrm{kg}$. In $91 \%$ of the samples, the OCDD was above the limit of quantification (LOQ). This means that significant concentrations of OCDD were noticed in crude palm oil (Fig. 2A), while the TEQ levels were well below the maximum level (Fig. 4A). Very few literature references have reported the occurrence of dioxin congeners in crude palm oil. Only Tuan Omar and co-authors (2014) found in their study that OCDD was the main congener present in crude palm oil (OCDD range 11-42 ng/kg) (Tuan Omar, Kuntom, \& Latiff, 2014), which is in line with the current study (Table 1). They concluded based on their data that the dioxin levels in the crude palm oil were acceptable but did not report the dioxin concentrations in the by-products.

In samples taken from the processing aid fresh bleaching earth, PCDD/Fs were also detected (Table 1). The PCDD/Fs have been detected before in various binder and anti-caking agents, such as kaolin, bentonite, and zeolite (Abad, Llerena, Saulo, Caixach, \& Rivera, 2002). In 2004, there was a serious incident related to kaolinic clay in the Netherlands (Hoogenboom et al., 2010). Halbert and Archer discussed that bleaching earth could be a possible root cause of PCDD/F contamination (Halbert \& Archer, 2007). Moreover, FEDIOL recognized the risk of the presence of PCDD/Fs in fresh bleaching earth. Therefore, for fresh bleaching earth, they specified a maximum level of $1.5 \mathrm{ng}$ $\mathrm{WHO}_{2005}$-TEQ/kg for PCDD/Fs and DL-PCBs (EFISC, 2014; FEDIOL, 2013a; Van Asselt and Sterrenburg, 2011). In the current study, the fresh bleaching earth samples did not exceed the TEQ limit specified by FEDIOL, the European vegetable oil and protein meal industry association. We calculated the potential contribution of fresh bleaching earth $(1 \%)$ to the TEQ value of palm oil. In the present study, the maximum level of dioxin in the bleaching earth samples was $1.15 \mathrm{ng}$ $\mathrm{WHO}_{2005}-\mathrm{TEQ} / \mathrm{kg}$. Based on the $1 \%$ bleaching earth, that is added to the process, the potential contribution to the TEQ is below $0.012 \mathrm{ng}$ $\mathrm{WHO}_{2005}-\mathrm{TEQ} / \mathrm{kg}$. Gibon and co-authors (2007) reported doses of 1-2\% (Gibon, De Greyt, \& Kellens, 2007), while Patterson (1992) reported doses of $1-1.5 \%$ for palm oil (Patterson, 1992). The risk assessment published by FEDIOL indicates doses of 1-3\% (EFISC, 2014). The $1 \%$ bleaching earth, therefore, represents the common doses, and the current study suggests that its contribution to TEQ is relatively low. Likewise, other researchers found a slight increase in dioxin levels in oil by a factor of 1.05 due to the use of fresh bleaching earth (Oterhals, Solvang, Nortvedt, \& Berntssen, 2007). In practice, a combination of fresh bleaching earth and activated carbon can be used. Activated carbon is used for the reduction of polycyclic aromatic hydrocarbons (PAH), but it can also be used to reduce PCDD/F levels (EFISC, 2014; Maes et al., 2005; Mounts, Dutton, Evans, \& Cowan, 1976; Oterhals et al., 2007). Consequently, the activated carbon can adsorb the dioxins and mitigate the possible increase due to the presence of dioxin in fresh bleaching earth.

After bleaching, the palm oil is deodorised to remove the free fatty acids (FFA) by using stripping steam at higher temperatures (about $270{ }^{\circ} \mathrm{C}$ ) under vacuum (physical refinery) (Patterson, 1992). During this process, the by-product palm fatty acid distillate (PFAD) is formed. Overall, the concentration of PCDD/F congeners in the PFAD samples was higher than that in the crude palm oil samples. Table 1 and Figs. 2C, 3C and 4C indicated that OCDD and HpCDD were concentrating in the palm fatty acid distillate (PFAD), resulting in $0.6 \%$ of the PFAD samples that exceeded the action level of $0.5 \mathrm{ng} \mathrm{WHO}_{2005}$ TEQ $/ \mathrm{kg}$. Nevertheless, all samples were below the maximum level of $0.75 \mathrm{ng} \mathrm{WHO}_{2005}-\mathrm{TEQ} / \mathrm{kg}$. There are only a few references related to the measurement of PCDD/Fs in PFAD. Van Asselt and Sterrenburg (2011) suggested that the dioxins (PCDD/Fs) in the crude palm oil may concentrate in the PFAD during the deodorising process (Van Asselt and Sterrenburg, 2011). The current study provided initial evidence for this concentration effect in the by-product. However, it is difficult to predict the TEQ in PFAD based on the concentrations of PCDD/Fs in the crude palm oil. One of the reasons is that not all congeners will evaporate in the same way. Several authors reported a reduction of PCDD/Fs in the palm oil during deodorisation due to evaporation and demonstrated that the evaporation rate depends on the characteristics of the individual PCDD/Fs as well as the processing conditions (De Greyt \& Kellens, 2005; Mounts et al., 1976; Oterhals, 2011; Oterhals et al., 2010). Kim and co-authors (2002) reported that the water solubility of TCDD is higher than that of HpCDD and OCDD (Kim, Masaki, Matsumura, Kamei, \& Magara, 2002). Another study demonstrated that the lower chlorinated PCDD/Fs with higher vapour pressure evaporate more easily (Zhao, Hou, Shimoda, Terada, \& Hosomi, 2012). Mount et al. (1976) observed that even 2,3,7,8-TCDD, which is a lower chlorinated dioxin than OCDD, was not completely removed from the oil. They found that $50 \%$ was removed after laboratory-scale deodorising for $1.5 \mathrm{~h}$ at $250^{\circ} \mathrm{C}$ (Mounts et al., 1976). De Greyt and Kellens (2005) reported a reduction of $11 \%$ in PCDD/Fs during deodorisation. The rate was dependent on the deodoriser temperature, the pressure, and the stripping steam (De Greyt and Kellens, 2005). This may explain why no RASFF alerts have been reported to date for refined palm oil, while there were rapid alerts for PFAD.

Part of the PFAD stream is hydrogenated, resulting in hydrogenated palm fatty acid distillate (HPFAD). The OCDD concentration was lower in the HPFAD samples compared to the OCDD concentration in the PFAD samples. However, the $\mathrm{WHO}_{2005}$-TEQ value in the HPFAD samples was higher compared to the PFAD samples. This was caused by the higher concentrations of $1,2,3,4,6,7,8-\mathrm{HpCDD}$, the three regulated 
HxCDDs, and 1,2,3,7,8-PeCDD (Table 1, Fig. 2C and D, 3C-D, and 4CD). In addition, the concentrations of the non-regulated congeners were higher (Fig. 5C and D) which is an indication for hydrodechlorination of the dioxin congeners during hydrogenation. Likewise, as reported by other authors, chlorine can be substituted by hydrogen during a hydrogenation process (Benítez \& Del Angel, 2009; Oterhals et al., 2007; Zhang, Chen, Zhang, Ni, \& Liang, 2007), which may generate congeners with higher toxicity factors or no toxicity factors depending on the type of congener.

\section{Conclusion}

The commercial crude palm oil samples investigated in this study contained dioxins and in particular OCDD and 1,2,3,4,6,7,8-HpCDD, but had TEQ levels below the maximum level due to low $\mathrm{WHO}_{2005}$-TEF values of OCDD and HpCDD. The impact of fresh bleaching earth on the dioxin concentration in the intermediate products seems low. In $0.6 \%$ of the PFAD samples (by-product of the deodorisation process), the TEQ value was above the action level but below the maximum level. The non-regulated $2,3,7,8$ congeners were between 21 and $36 \%$ of the total PCDD/F level in 6 selected PFAD samples. The PFAD can be hydrogenated, resulting in HPFAD. Of the 378 monitoring samples, $1.3 \%$ was above the regulatory limit. In five HPFAD samples, the non-2,3,7,8 congener concentrations were between 49 and $84 \%$ of the total PCDD/F concentrations. The concentration of the lower chlorinated 2,3,7,8PCDD/F congeners in these samples was higher than in PFADs, resulting in higher TEQ levels, 0.25 till $1.82 \mathrm{ng} \mathrm{WHO}_{2005}$-PCDD/F-TEQ/ $\mathrm{kg}$. It is hypothesized that during the hydrogenation process, dechlorination of OCDD occurs in the regulated and non-regulated dioxin congeners. It is important to understand the concentration at intake, the change in concentration during processing and the impact on the toxicity profile. For the optimization of the control measures, the source of OCDD, and the impact of hydrogenation on the individual PCDD/F congener should be further investigated.

\section{Acknowledgements}

This study was performed in close cooperation with RIKILT, Cargill B.V., and the Dutch Food and Consumer Products Safety Authority (NVWA). The authors are grateful for the support for this investigation. They are grateful for the contribution of Wim Traag, a former employee of RIKILT. We would like to thank Editage for English language editing as well.

\section{Appendix A. Supplementary data}

Supplementary data to this article can be found online at https:// doi.org/10.1016/j.foodcont.2019.106777.

\section{References}

Abad, E., Llerena, J. J., Saulo, J., Caixach, J., \& Rivera, J. (2002). Comprehensive study on dioxin contents in binder and anti-caking agent feed additives. Chemosphere, 46(9-10), 1417-1421. https://doi.org/10.1016/S0045-6535(01)00274-0.

Abraham, K. A., K.E., Appel, Berg, K., Heinemeyer, G., Lahrssen-Wiederholt, M., Large, N., et al. (2011). Review: Die vorkommnisse um dioxin in futtermitteln in Deutschland 2011-gab es ein risiko für verbraucher? Journal of Food Safety and Food Quality, 62, 105-144.

Benítez, J. L., \& Del Angel, G. (2009). Total hydrodechlorination of industrial transformer oil on metal-supported catalysts Chemical Engineering Communications. Vol. 196. Total hydrodechlorination of industrial transformer oil on metal-supported catalysts Chemical Engineering Communications (pp. 1217-1226). . (10) https://doi.org/10.1080/ 00986440902831888.

De Greyt, W., \& Kellens, M. (2005). Deodorization. In F. Shahidi (Ed.). Bailey's industrial oil and fat products. John Wiley \& Sons, Inc.

De Meulenaer, B. (2006). Chemical hazards. In P. A. Luning, F. Devlieghere, \& R. Verhé (Eds.). Safety in the agri-food chain (pp. 145-208). Wageningen: Wageningen Academic Publishers.

Directorate-General_for_Health\&Consumers (2011). The rapid alert system for food and feed (RASFF) annual report 2010. (p. 59)Luxembourg: European Commission.
Directorate-General_for_Health\&Consumers (2013). RASFF the rapid alert system for food and feed 2012 annual report. (p. 54)Luxembourg: European Commission.

EC (2006). Commission Regulation (EC) No 1881/2006 setting maximum levels for certain contaminants in foodstuffs. Official Journal of the European Communities, 364, 5-24. http://www.fao.org/faolex/results/details/en/c/LEX-FAOC068134/.

EC (2011). Commission Regulation (EU) No 1259/2011 amending Regulation (EC) No $1881 / 2006$ as regards maximum levels for dioxins, dioxin-like PCBs and non dioxinlike PCBs in foodstuffs. Official Journal of the European Union, 320, 18-23. http:// www.fao.org/faolex/results/details/en/c/LEX-FAOC108087/.

EC (2012). Commission Regulation (EU) No 277/2012 amending Annexes I and II to Directive 2002/32/EC of the European Parliament and of the Council as regards maximum levels and action thresholds for dioxins and polychlorinated biphenyls. Official Journal of the European Union, 91, 1-7. https://doi.org/10.3000/19770677.L. 2012.091.eng.

EC (2014a). Commission Regulation (EU) No 589/2014 laying down methods of sampling and analysis for the control of levels of dioxins, dioxin-like PCBs and non-dioxin-like PCBs in certain foodstuffs and repealing Regulation (EU) No 252/2012. Official Journal of the European Union, 164, 18-40. http://faolex.fao.org/cgi-bin/faolex.exe? rec $\_i d=134439 \&$ database $=$ faolex\&search $\_$type $=$link\&table $=$result\&lang $=$eng $\&$ format name=@ERALL.

EC (2014b). Commission Regulation (EU) No 589/2014 of 2 June 2014 laying down methods of sampling and analysis for the control of levels of dioxins, dioxin-like PCBs and non-dioxin-like PCBs in certain foodstuffs and repealing Regulation (EU) No 252/ 2012. Official Journal of the European Union, L164, 18-40. http://eur-lex.europa.eu/ legal-content/EN/TXT/?uri = uriserv:OJ.L_.2014.164.01.0018.01.ENG.

EC (2014c). Commission Regulation (EU) No 709/2014 amending Regulation (EC) No $152 / 2009$ as regards the determination of the levels of dioxins and polychlorinated biphenyls. Official Journal of the European Union, 188, 1-18. http://faolex.fao.org/cgibin $/$ faolex.exe?rec_id $=135068 \&$ database $=$ faolex\&search_type $=$ link\&table $=$ result \&lang $=$ eng\&format name $=@$ ERALL.

EFISC (2014). Sector reference document on the manufacturing of safe feed materials from oilseed crushing and vegetable oil refining version 3.1. Brussels: EFISC Aisbl140.

EFSA (2010). Results of the monitoring of dioxin levels in food and feed. EFSA Journal, 8(3), 36. 1385 https://doi.org/10.2903/j.efsa.2010.1385.

EFSA (2012a). Scientific opinion on the presence of dioxins (PCDD/F) and dioxin-like PCBs (DL-PCBs) in commercially available foods for infants and young children. EFSA Journal, 10(12), 29. 2983 https://doi.org/10.2903/j.efsa.2012.2983.

EFSA (2012b). Update of the monitoring of levels of dioxins and PCBs in food and feed. EFSA Journal, 10(7), 82. 2832 https://doi.org/10.2903/j.efsa.2012.2832.

EFSA (2018). Risk for animal and human health related to the presence of dioxins and dioxin-like PCBs in feed and food. EFSA Journal, 16(11), 331. 5333 https://doi.org/ 10.2903/j.efsa.2018.5333.

FEDIOL (2013a). Code of Practice on the purchase conditions of fresh bleaching earth and filter aids for vegetable oils and fats refineries and integrated plants. Retrieved from http://www.fediol.eu/web/codes\%20of\%20practice/1011306087/list1187970091/ f1.html, Accessed date: 20 May 2014.

FEDIOL (2013b). European Code to good practice for the industrial manufacture of safe feed materials - sector reference document on the manufacturing of safe feed materials from oilseed crushing and vegetable oil refining. Retrieved from http://www.efisc.eu/data/, Accessed date: 20 May 2014.

Gibon, V., De Greyt, W., \& Kellens, M. (2007). Palm oil refining. European Journal of Lipid Science and Technology, 109(4), 315-335. https://doi.org/10.1002/ejlt.200600307.

Halbert, M. K., \& Archer, J. C. (2007). Dioxin and furan contamination of deodorizer distillates and natural vitamin E supplements. Journal of Food Composition and Analysis, 20(6), 506-514. https://doi.org/10.1016/j.jfca.2007.02.010.

Hoogenboom, L. A. P., Zeilmaker, M. J., Van Eijkeren, J., Kan, C. A., Mengelers, M., Luykx, D., et al. (2010). Kaolinic clay derived PCDD/Fs in the feed chain from a sorting process for potatoes. Chemosphere, 78(2), 99-105. https://doi.org/10.1016/j. chemosphere.2009.10.016.

Jackson, L. S. (2009). Chemical food safety issues in the United States: Past, present, and future. Journal of Agricultural and Food Chemistry, 57(18), 8161-8170. https://doi. org $/ 10.1021 /$ jf900628u.

Kim, H. K., Masaki, H., Matsumura, T., Kamei, T., \& Magara, Y. (2002). Removal efficiency and homologue patterns of dioxins in drinking water treatment. Water Research, 36(19), 4861-4869. https://doi.org/10.1016/S0043-1354(02)00202-6.

Maes, J., De Meulenaer, B., Van Heerswynghels, P., De Greyt, W., Eppe, G., De Pauw, E., et al. (2005). Removal of dioxins and PCB from fish oil by activated carbon and its influence on the nutritional quality of the oil. Journal of the American Oil Chemists Society, 82(8), 593-597. https://doi.org/10.1007/s11746-005-1114-1.

Mounts, T. L., Dutton, H. J., Evans, C. D., \& Cowan, J. C. (1976). Chick edema factor: Removal from soybean oil. Journal of the American Oil Chemists Society, 53(3), 105-107. https://doi.org/10.1007/BF02635959.

Oterhals, A. (2011). Decontamination of persistent organic pollutants in fishmeal and fish oil. Process optimization and modeling. (p. 92): The University of Bergen.

Oterhals, Å., Kvamme, B., \& Berntssen, M. H. G. (2010). Modeling of a short-path distillation process to remove persistent organic pollutants in fish oil based on process parameters and quantitative structure properties relationships. Chemosphere, $80(2)$, 83-92. https://doi.org/10.1016/j.chemosphere.2010.04.016.

Oterhals, A.., Solvang, M., Nortvedt, R., \& Berntssen, M. H. G. (2007). Optimization of activated carbon-based decontamination of fish oil by response surface methodology. European Journal of Lipid Science and Technology, 109(7), 691-705. https://doi.org/ 10.1002/ejlt.200700083.

Patterson, H. B. W. (1992). Bleaching and purifying fats and oils: Theory and practice. Champaign, Illinois: American Oil Chemists' Society (AOCS).

Schecter, A. J., Birnbaum, L. S., Ryan, J. J., \& Constable, J. D. (2006). Dioxins: An overview. Environmental Research, 101(3), 419-428. https://doi.org/10.1016/j. 
envres.2005.12.003.

TNS Opinion\&Social (2010). Special eurobarometer 354 food-related risks, conducted by TNS Opinion\&Social at the request of the european food safety authority (EFSA). EFSA (p. 78). Parma: EFSA Publications Office.

Tuan Omar, T. F., Kuntom, A., \& Latiff, A. A. (2014). Assessment of dioxins and dioxinlike polychlorinated biphenyls in the palm oil supply chains. Quality Assurance and Safety of Crops \& Foods, 1, 1-8. https://doi.org/10.3920/qas2012.0221.

Van Asselt, E. D., \& Sterrenburg, P. (2011). Dioxin monitoring in fats oils for the feed industry Wageningen, NL. Rikilt - Institute of Food Safety.

Van den Berg, M., Birnbaum, L. S., Denison, M., De Vito, M., Farland, W., Feeley, M., ... Peterson, R. E. (2006). The 2005 World Health Organization reevaluation of human and mammalian toxic equivalency factors for dioxins and dioxin-like compounds. Toxicological Sciences, 93(2), 223-241. https://doi.org/10.1093/toxsci/kfl055.

Zhang, F., Chen, J., Zhang, H., Ni, Y., \& Liang, X. (2007). The study on the dechlorination of OCDD with Pd/C catalyst in ethanol-water solution under mild conditions. Chemosphere, 68(9), 1716-1722. https://doi.org/10.1016/j.chemosphere.2007.03. 056.

Zhao, L., Hou, H., Shimoda, K., Terada, A., \& Hosomi, M. (2012). Formation pathways of polychlorinated dibenzofurans (PCDFs) in sediments contaminated with PCBs during the thermal desorption process. Chemosphere, 88(11), 1368-1374. https://doi.org/ 10.1016/j.chemosphere.2012.05.042. 